\title{
A Preliminary Search for the Relationship between Irrigation and Cropping Intensity in Birbhum District of West Bengal
}

\author{
Sandipan Ganguly \\ Junior Research Fellow in Geography \\ The University of Burdwan \\ sandipan.suri@gmail.com \\ Palash Patra \\ Assistant Teacher in Geography \\ Ghoga Junior High School \\ iampalashpatra@gmail.com
}

\begin{abstract}
Irrigation is the most important input for crop production in any region. Cropping intensity is an important indicator of the status of cultivation in any region. Hence an attempt has been made in this paper to search for the simple relationship between irrigation and cropping intensity using the Karl Pearson's Product Moment Correlation method in the C.D. blocks of Birbhum district of West Bengal where rainfall is seasonally concentrated and unreliable. The paper reveals that the eastern C.D. blocks enjoy high status of irrigation and cropping intensity over the dry, elevated western blocks of the district. There exists a moderate positive correspondence between the two variables which indicates that the cropping intensity in various blocks of the district is not solely governed by irrigation but by other natural, socio-cultural, economic, political, technological and infrastructural factors. If irrigation is considered as the driving element then it's both surface and groundwater sources have almost equal association with the intensity of cropping of the district. Through the effective management of water resources, Birbhum district will be able to achieve high status in terms of crop cultivation.
\end{abstract}

Keywords: Agriculture, Correlation, Cultivation, Irrigation, Cropping intensity.

\section{INTRODUCTION}

The monsoon climate of India is characterized by uneven distribution of rainfall. But water is considered as an important input for crop cultivation. As India's economy heavily depends on its agriculture, it is important to ensure a continuous supply of water to the agricultural fields. To overcome the problems of rainfall deficiency and short supply of water to crops, irrigation provisions in the form of canals, wells, tube wells and tanks have been made. Groundwater is also considered as one of the important sources of irrigation. Since the occurrence of Green Revolution in the mid sixties, the scenario of Indian agriculture experienced a drastic change with the adoption of high yielding varieties of seeds and chemical fertilizer. The use of these inputs pre-required the development of assured irrigation (Singh, 1977).Thus the cropping pattern of a region is largely determined by its existing irrigation facilities. For a proper assessment of the potentiality of crop production of a region, it is essential to have an enquiry into the relationship between its irrigation and cropping intensity.

\subsection{The Study Area}

Birbhum district lies between $23^{\circ} 32^{\prime} 30^{\prime \prime} \mathrm{N}$ to $24^{0} 35^{\prime} 00^{\prime \prime} \mathrm{N}$ and $87^{\circ} 05^{\prime} 25^{\prime \prime} \mathrm{E}$ to $88^{\circ} 01^{\prime} 40^{\prime \prime} \mathrm{E}$. It is the northernmost district of the Burdwan division and is situated at the west boundary of the state of West Bengal (Fig. 1). It is separated from the district of Burdwan by the river Ajay. Birbhum district is characterized by undulating topography. The land situation is gradually slopped down from the west to the flat plains that appear in the furthest of the district. The area of the district lies under 3 AgroClimatic Zones of the state namely 1)Gangetic Alluvial Zone, 2)Vindhyan Alluvial Zone and 3)Undulating Red and Laterite Zone. Birbhum district has a total geographical area of 454500 
hectares of which 320610 hectares $(70.54 \%)$ is under cultivation. Out of the total area under cultivation, $54.58 \%$ area is covered by irrigation.

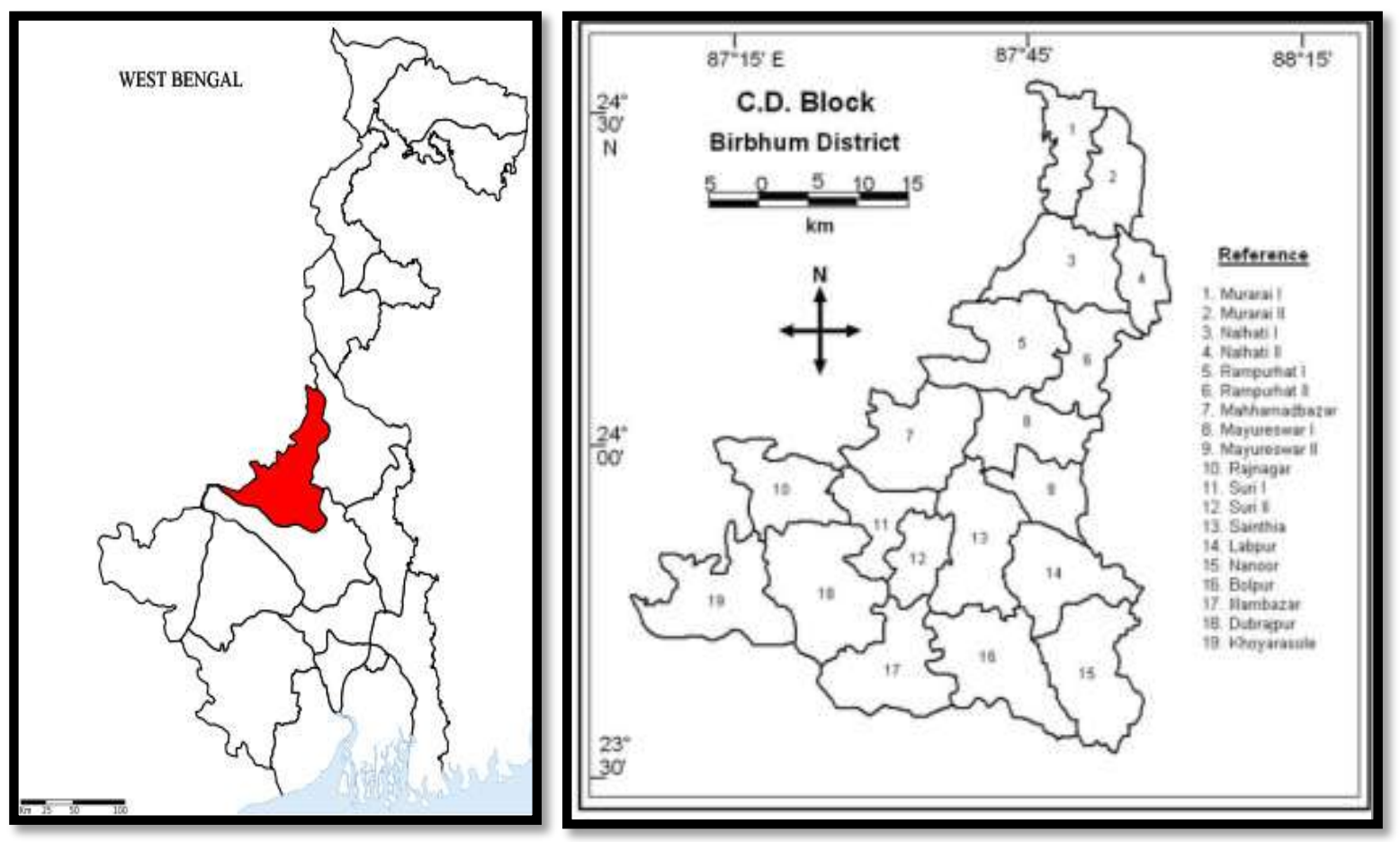

Fig1. Location of Birbhum District

The major cropping pattern of the district is Aman paddy/Aus paddy/Wheat/Vegetable/Oilseeds/Pulses/Boro paddy.

\section{OBJECTIVES}

$>$ To delineate the C.D. blocks of Birbhum district on the basis of their irrigation intensity and cropping intensity.

$>$ To find out the relationship between irrigation intensity and cropping intensity in the C.D. blocks of Birbhum district.

$>$ To find out the degree of correspondence among the percentage share of different sources of irrigation in terms of gross irrigated area and cropping intensity in the district.

\subsection{Data Sources and Methodology}

The present study is based on the secondary data which have been collected from the District Statistical Handbook of Birbhum, 2008 and Office of the Deputy Director of Agriculture (Admin), Birbhum.

The collected data have been analysed with the help of suitable statistical and cartographic techniques. The following formulae have been applied:

Irrigation Intensity $=($ Gross Irrigated Area $/$ Gross Cropped Area $) \times 100$

$>$ Cropping Intensity $=($ Gross Cropped Area $/$ Net Sown Area $) \times 100$

$>$ The relationship between irrigation intensity and cropping intensity and the degree of correspondence among the percentage share of different sources of irrigation in terms of gross irrigated area and cropping intensity of the C.D. blocks of the district have been shown with the help of Co-efficient of Correlation (Karl Pearson, 1896) formula, linear regression and residual mapping.

\section{RESULTS AND DISCUSSIONS}

On the basis of irrigation intensity and cropping intensity (Table 1), the C.D. blocks of Birbhum district have been categorized into three distinct zones i.e. high, moderate and low (Fig. 2). 
A Preliminary Search for the Relationship between Irrigation and Cropping Intensity in Birbhum District of West Bengal

Table1. Irrigation Intensity and Cropping Intensity in Birbhum District, 2007-08

\begin{tabular}{|c|c|c|c|c|c|}
\hline C.D Blocks & $\begin{array}{c}\text { Net Sown } \\
\text { Area } \\
\text { (in hc) }\end{array}$ & $\begin{array}{c}\text { Gross Cropped } \\
\text { Area (in hc) }\end{array}$ & $\begin{array}{c}\text { Gross Irrigated } \\
\text { Area (in hc) }\end{array}$ & $\begin{array}{c}\text { Irrigation } \\
\text { Intensity } \\
\text { (in \%) }\end{array}$ & $\begin{array}{c}\text { Cropping } \\
\text { Intensity } \\
\text { (in \%) }\end{array}$ \\
\hline Suri-I & 9940 & 12214 & 6243 & 51.11 & 122.88 \\
\hline Suri-II & 9690 & 17360 & 13772 & 69.33 & 179.15 \\
\hline Sainthia & 21415 & 36120 & 25501 & 70.60 & 168.67 \\
\hline Dubrajpur & 22810 & 29779 & 15273 & 51.29 & 130.55 \\
\hline Khoyrasole & 19630 & 22845 & 11061 & 48.42 & 116.38 \\
\hline Rajnagar & 13530 & 14393 & 5397 & 37.50 & 106.38 \\
\hline Md. Bazar & 22130 & 25595 & 11110 & 43.41 & 115.66 \\
\hline Bolpur-Sriniketan & 21660 & 36795 & 26221 & 71.26 & 169.88 \\
\hline Illambazar & 18180 & 27182 & 19968 & 73.46 & 149.52 \\
\hline Labhpur & 20730 & 31440 & 24048 & 76.49 & 151.66 \\
\hline Nanoor & 22050 & 38003 & 30254 & 79.61 & 172.35 \\
\hline Mayureswar-I & 15870 & 27691 & 20800 & 75.11 & 174.49 \\
\hline Mayureswar-II & 10870 & 22348 & 10216 & 45.71 & 205.59 \\
\hline Rampurhat-I & 20325 & 26947 & 16981 & 63.02 & 132.58 \\
\hline Rampurhat-II & 15710 & 29428 & 19704 & 66.96 & 187.32 \\
\hline Nalhati-I & 18880 & 29342 & 15027 & 51.21 & 155.51 \\
\hline Nalhati-II & 8700 & 18505 & 12608 & 68.13 & 212.70 \\
\hline Murarai-I & 13760 & 25085 & 11210 & 44.69 & 182.30 \\
\hline Murarai-II & 14730 & 25722 & 20180 & 78.45 & 174.62 \\
\hline
\end{tabular}

Source: District Statistical Handbook of Birbhum, 2008 and Primary Computation

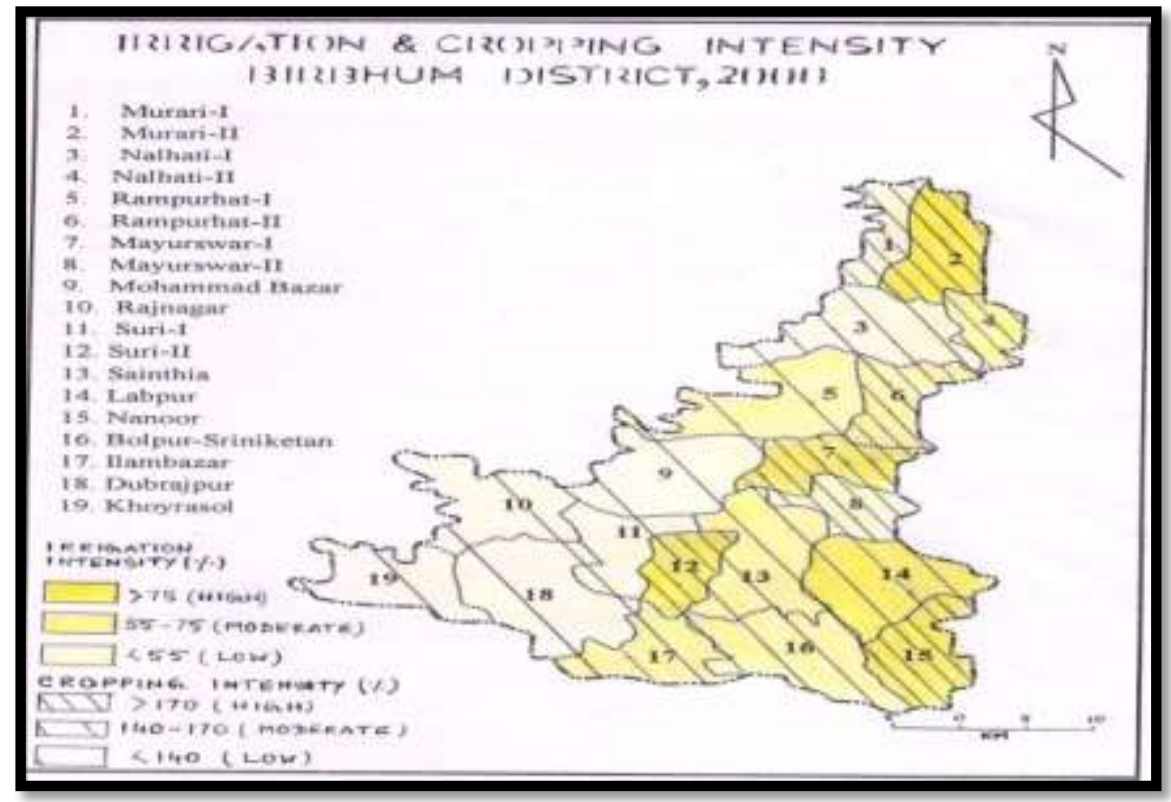

Fig2. Irrigation and Cropping Intensity Zones, Birbhum District, 2008

Normally an overall increase of gross cropped area in the net sown area is discernible over the region. This indicates that the double and multiple croplands are being served by assured water supply in terms of irrigation. The superimposed map (Fig. 2) clearly depicts that the blocks with high cropping intensity i.e. Murarai II, Mayureswar I, Suri II, Nanoor have high irrigation intensity except Rampurhat II which falls under the moderate irrigation intensity zone. Similarly the blocks with low irrigation intensity i.e. Md. Bazar, Rajnagar, Suri I, Khoyrasole and Dubrajpur record low cropping intensity except Murarai I and Nalhati I which record high and moderate cropping intensity respectively. This is the general pattern of the district.

The relationship between irrigation intensity and cropping intensity of the C.D. blocks of the district has been assessed with the help of Co-efficient of Correlation after Karl Pearson, 1986. In this part of analysis, irrigation intensity and cropping intensity have been considered as independent (X) and 
dependent variables (Y) respectively (Fig. 3). From the arrangement of dots and orientation of best fit line $\left(\mathrm{Y}_{\mathrm{C}}=\mathrm{a}+\mathrm{bx}\right)$, it is clear that both the variables are positively correlated. The calculated value of Pearson's Correlation Co-efficient is 0.47 for the district as a whole and blocks in particular signifies that there is a moderate positive association between irrigation intensity and cropping intensity.

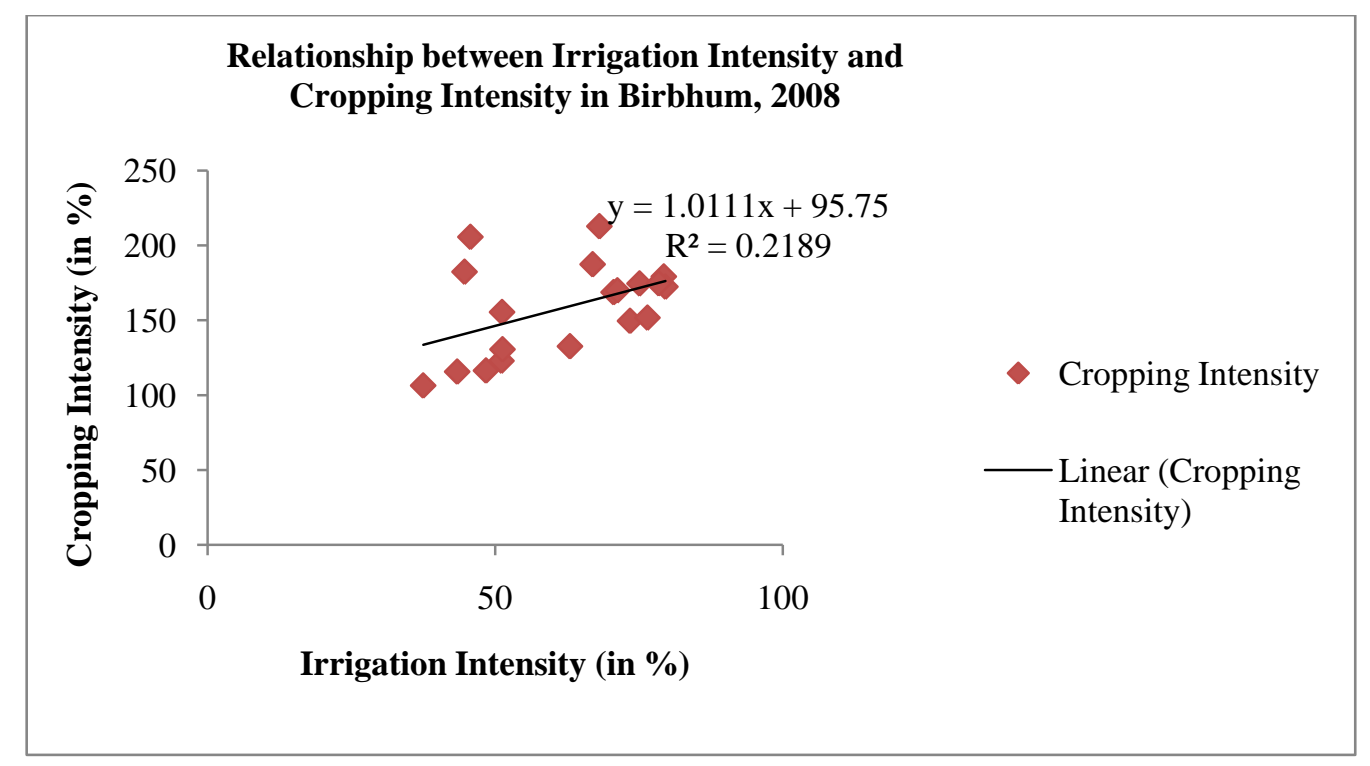

Fig3

The percentage share of different sources of irrigation (in terms of gross irrigated area) in the C.D. blocks of Birbhum district has been shown in the Fig. 4. To investigate what type of irrigation has more impact on the cropping intensity in the C.D. blocks as well as the district as a whole, an analysis of degree of correspondence among the different sources of irrigation and cropping intensity in the C.D. blocks has been done with the help of Co-efficient of Correlation after Karl Pearson, 1896.

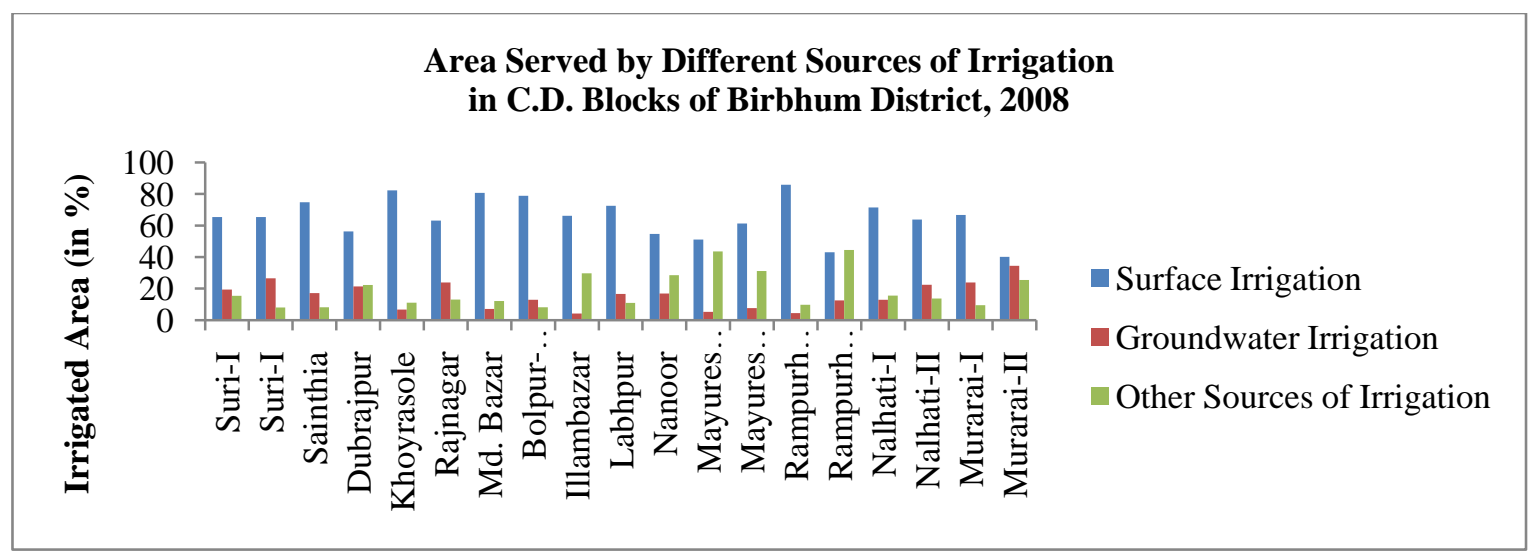

Fig4

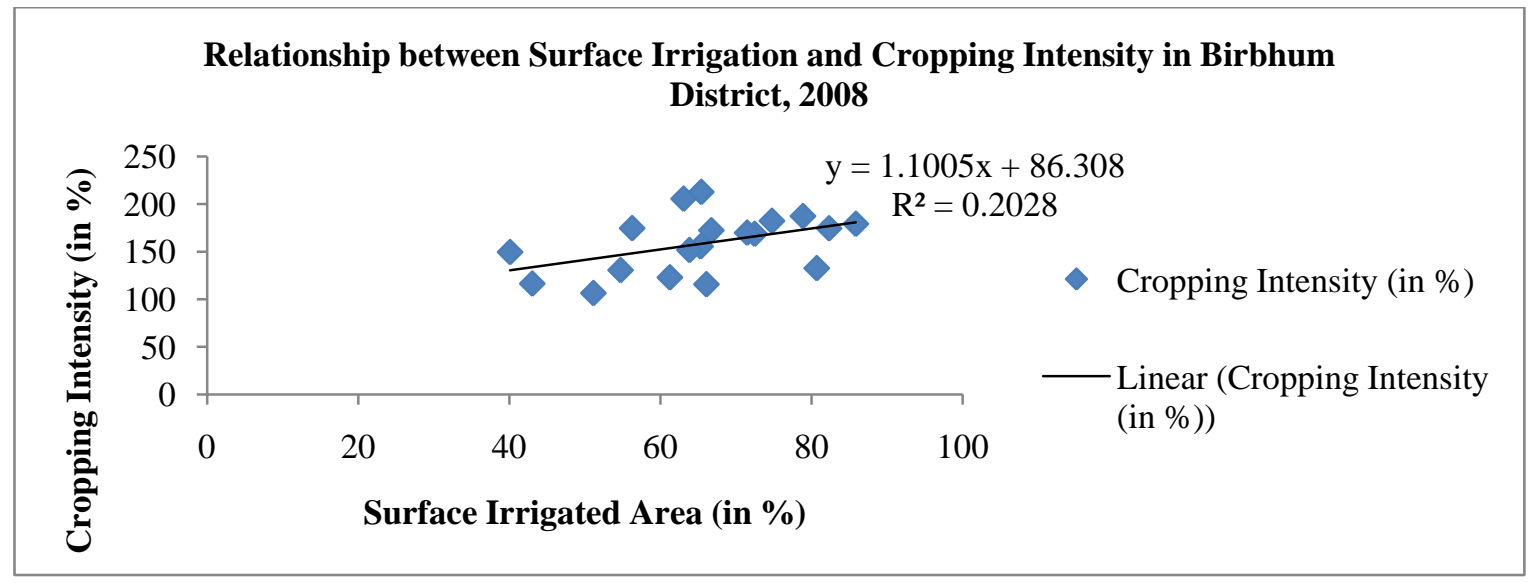

Fig5.1 
A Preliminary Search for the Relationship between Irrigation and Cropping Intensity in Birbhum District of West Bengal

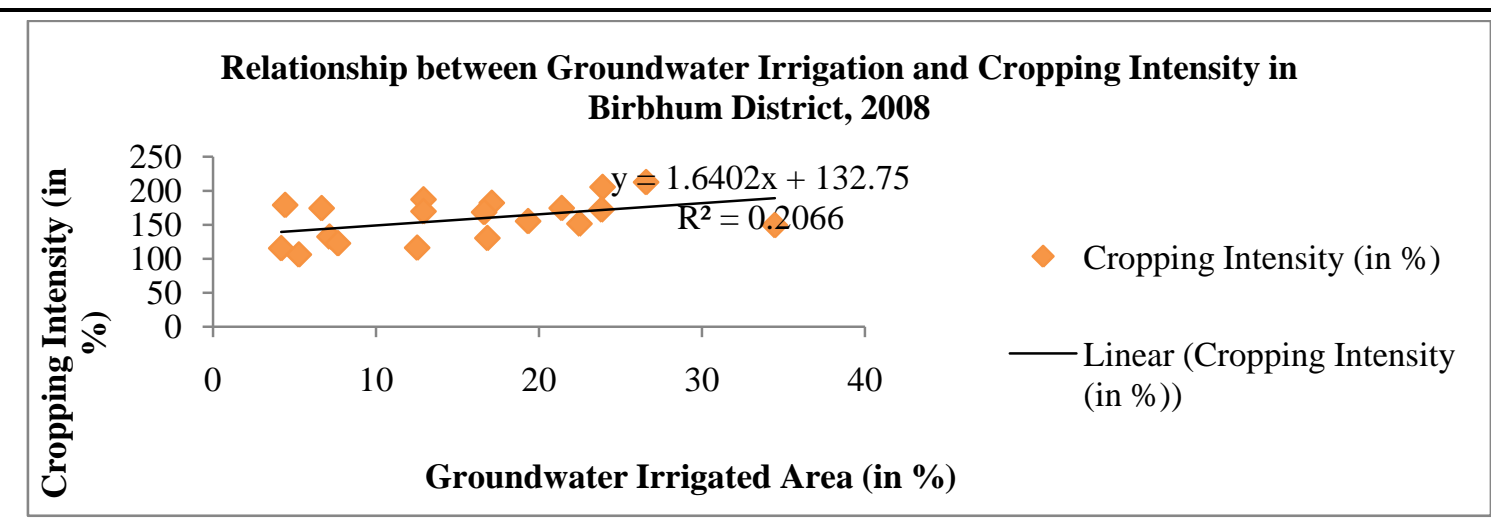

Fig5.2

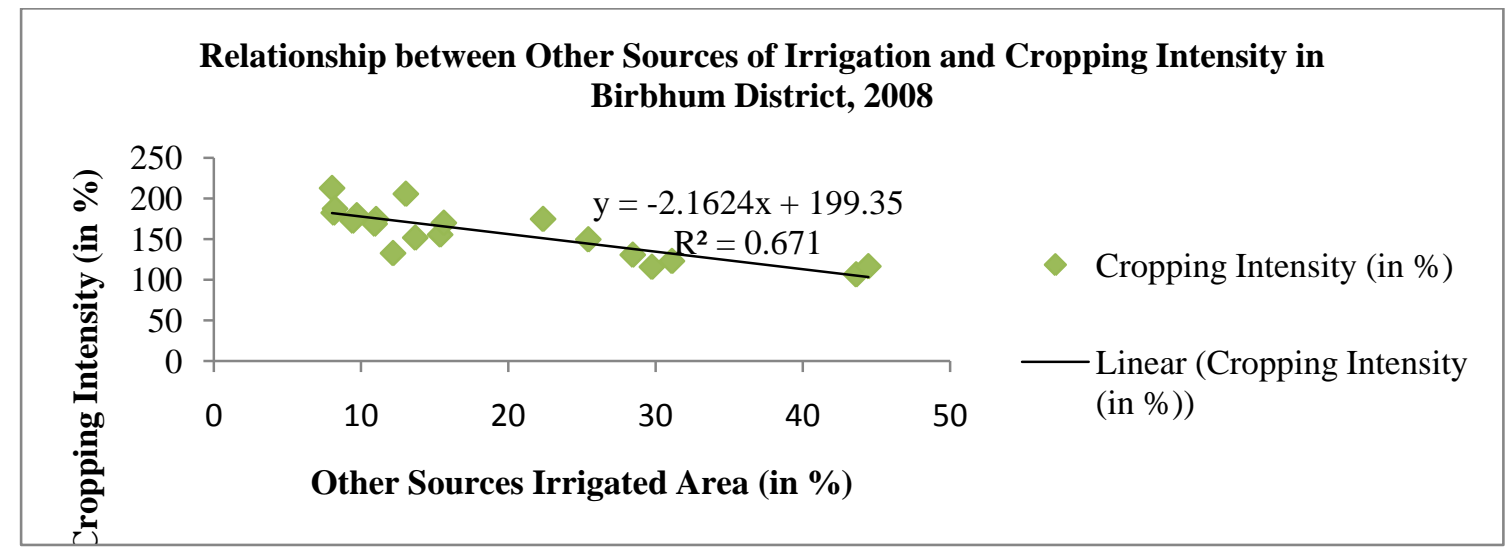

Fig. 5.3

The linear regression analysis (Fig. 5.1, 5.2 and 5.3) show that both surface irrigation (which includes canal, tank and river lift irrigation) and groundwater irrigation (includes deep tube well, shallow tube well and open dug well) individually have positive impact on cropping intensity with moderate correspondence (Pearson's Correlation of Co-efficient is 0.45) except other sources of irrigation which strangely have a high negative association with cropping intensity $(-0.82)$.

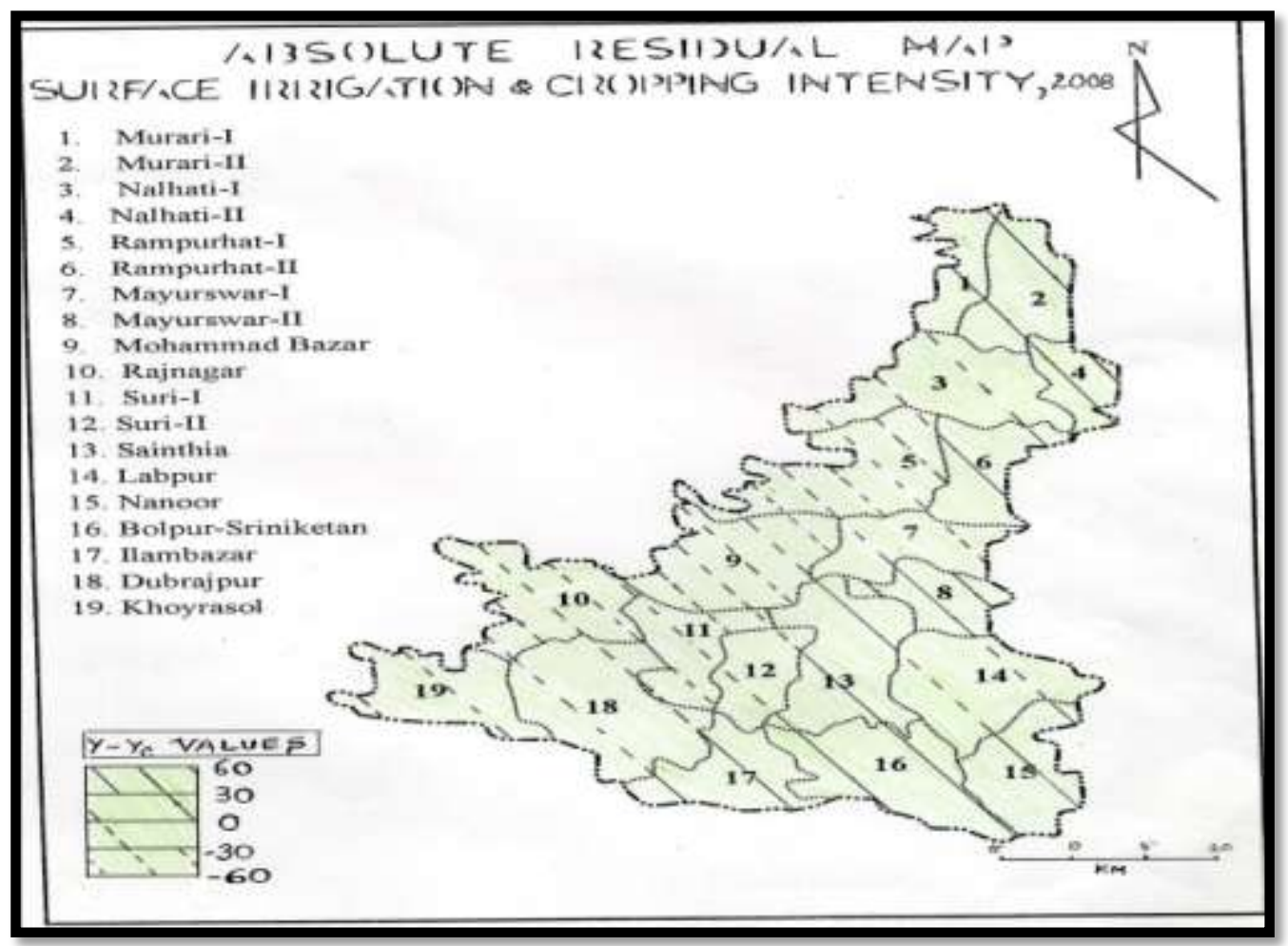

Fig6. Cropping Intensity in respect of Surface Irrigation, Birbhum District, 2008 
The block wise association between the percentage share of surface and groundwater irrigated area and cropping intensity have been shown with the help of absolute residual mapping (Fig. $6 \&$ 7). The lower values (both positive and negative values) of the residuals $\left(\mathrm{Y}-\mathrm{Y}_{\mathrm{c}}\right)$ portray the zones of strong correspondence and the higher values (both positive and negative values) denote lesser correspondence between the two variables in each figure.

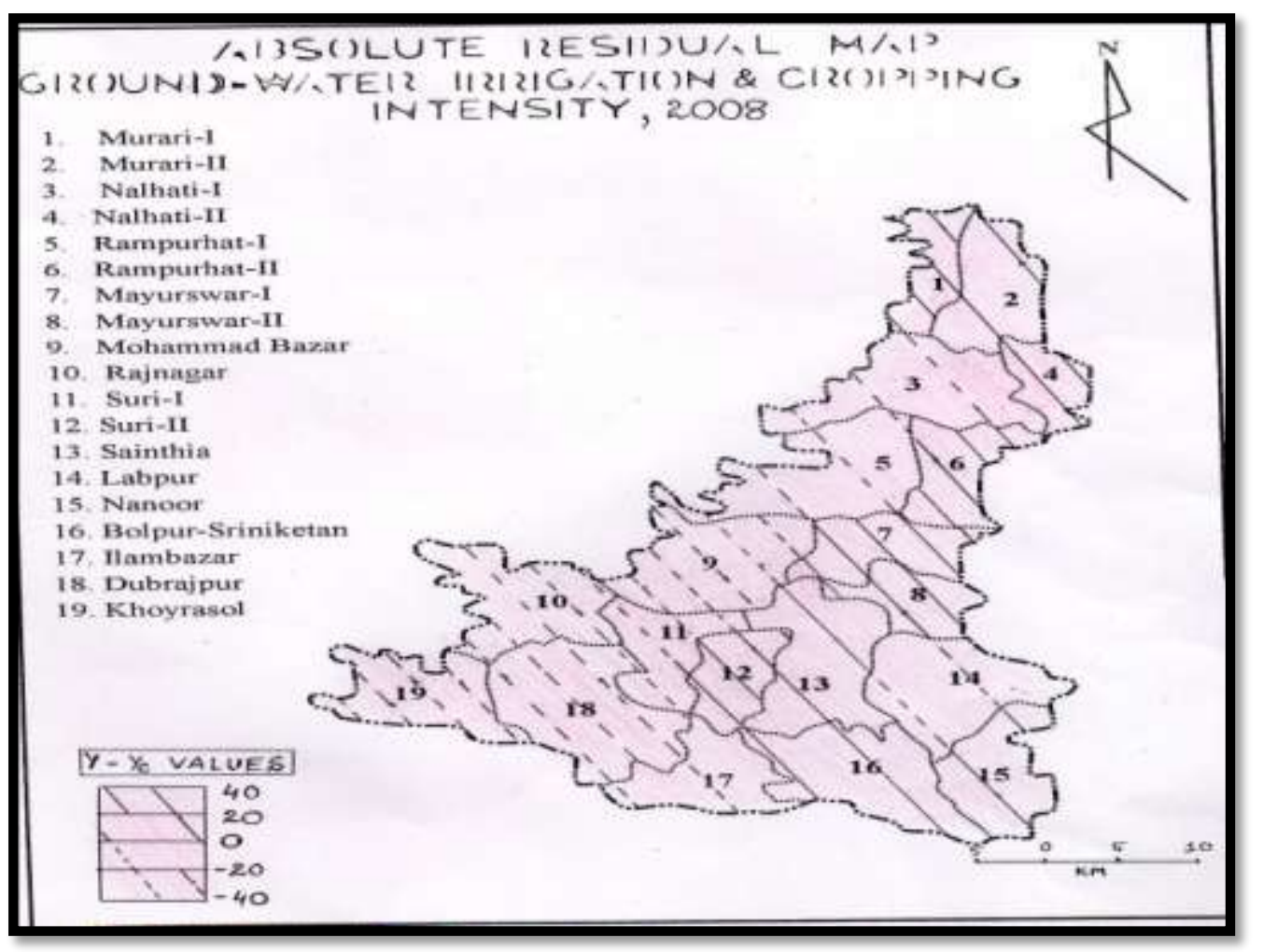

Fig7. Cropping Intensity in respect of Groundwater Irrigation, Birbhum District, 2008

\section{Conclusion}

From the overall analysis, it can be said that the eastern C.D. blocks enjoy high status of irrigation and cropping intensity over the western blocks of the district. The undulating topography due to the proximity to the Chotonagpur plateau in the western part and the fertile tract of the Gangetic plain in the eastern part of the district are responsible for its block level disparity in terms of irrigation and cropping intensity. The study also brings out the fact that there is a moderate positive correspondence between irrigation intensity and cropping intensity in the C.D. blocks which further indicates that the cropping intensity in Birbhum district is not solely dependent on the irrigation but on the other natural, socio-cultural, economic, political, technological and infrastructural factors. The analysis of degree of correspondence among different sources of irrigation and cropping intensity in the C.D. blocks clearly indicate that both the surface and ground water irrigation have almost same impact on the cropping intensity of the district. But the groundwater resource of most blocks of the district has been over exploited and groundwater level is declining day by day. It is a serious problem for any agricultural production. It calls for immediate attention to develop some alternate rainwater harvesting techniques which will reduce the excessive use of groundwater. The rational utilization of the different sources of irrigation will enhance the block level scenario of cropping intensity of Birbhum district and make it one of the agriculturally sound districts of West Bengal.

\section{REFERENCES}

[1] Bhalla G. S., Indian Agriculture since Independence, National Book Trust, New Delhi, pp 133 (2008).

[2] Chakraborty A., Study on Growth of Major Agricultural Crops in Birbhum District, Scholars Journal of Agriculture and Veterinary Sciences, 2(1B), pp 63-66 (2015).

[3] District Statistical Handbook: Birbhum, Bureau of Applied Economics \& Statistics, Kolkata, Government of West Bengal (2008). 
[4] Dubey R. S., Agricultural Geography, issues and applications, Gian Publishing House, Bombay (1987).

[5] Dutta S., Ground Water Utilization and Cropping Pattern: A Geographical Investigation in Hugli District in West Bengal, Geo-Analyst, 1, pp 73-81 (2013).

[6] Haque S., Impact of Irrigation on Cropping Intensity and Potentiality of Groundwater in Murshidabad District of West Bengal, India, International Journal of Eco-system, 5 (3A), pp 5564 (2015).

[7] Husain M., Systematic Agricultural Geography, Rawat Publications, Jaipur (2008).

[8] Karunakaran K. R. and Palanisami K., An Analysis of Impact of Irrigation on Cropping Intensity in Tamil Nadu, Indian Economic Review, 33(2), pp 207-220 (1998).

[9] Let S., Crop Diversification of Birbhum District: A Spatio Temporal Assessment, Geo-Analyst, 1(2), pp 23-28 (2013).

[10] Mukhopadhyay S., Identifying the Problems and Prospects of Agricultural Development in Birbhum District, Geo-Analyst, 3, pp 59-72 (2013).

[11] www.birbhum.gov.in/DDAgri/PAO.htm, accessed on 10/12/2015.

\section{AUTHORS' BIOGRAPHY}

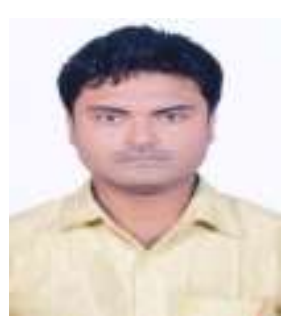

Sandipan Ganguly, completed M.A. in Geography from the University of Burdwan in 2011. He was awarded NET-JRF by UGC in 2014. He received M.Phil degree in Geography in 2015 from Mewar University, Rajasthan. He has two years teaching experience as a Guest Lecturer in Geography in an undergraduate college in W.B. His area of interest is Urban and Agricultural Geography. He has a dozen of research papers on his credit, published in different national and international journals. Presently he is pursuing Ph. D in Geography at the University of Burdwan in W.B.

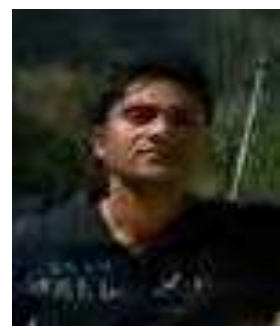

Palash Patra, post-graduated in Geography from the University of Burdwan in 2011. He has qualified both CSIR and UGC-NET in 2012. His research interest is in Geomorphology and Agricultural Geography. He has published 5 research papers in different journals. He is presently working as an Assistant Teacher in Geography in a Junior High School in W.B 